\title{
Introduction: Setting the Stage
}

\author{
Tuula Sakaranaho, Timo Aarrevaara, and Johanna Konttori
}

\begin{abstract}
Religion has become a pressing matter in different fields of multicultural European society, which raises the question as to how best to govern religious diversity. What we argue in this book is that a successful governance of religious diversity necessitates the development of religious literacy. As such, religious literacy can be understood in a variety of ways depending on the particular context. This book draws on different empirical case studies concerning Finland, covering traditional Finnish religious movements and issues pertaining to immigration and the growing ethnic and religious diversity of Finnish society. In doing so, it delves, among other matters, into the field of school education and state policies against radicalization and violence.
\end{abstract}

Keywords Religious literacy $\cdot$ Diversity $\cdot$ Governance $\cdot$ Finland

\section{Pitfalls of Religious Illiteracy}

In contemporary European society, approaches towards religion in the public sphere tend to be very contradictory. In the 1960s, many sociologists envisaged that the process of secularization would result in religion becoming obsolete in the European public sphere and hence relegated solely to the private sphere of personal belief and practice. This has not happened, however. For instance, religion is regularly in the headlines of world politics and security issues. In particular, social media has become a medium for personal opinions and even a platform for hate talk, in which religion is seen as a root cause of social problems faced by a multicultural European society. At the same time, the importance of religion in the public sphere is not necessarily recognized, or it is avoided as an awkward subject, due to the idea that religion does not concern the secular world. In the latter case, religion is seen as a matter best left

T. Sakaranaho $(\bowtie) \cdot$ J. Konttori

University of Helsinki, Helsinki, Finland

e-mail: tuula.sakaranaho@helsinki.fi

T. Aarrevaara

University of Lapland, Rovaniemi, Finland 
aside in the work of administrators and in the health and service sectors. In practice, the price paid for this line of thought is the spread of religious illiteracy.

In our view, religion is a pressing matter in all fields of a plural society. This raises the question of how best to govern religious diversity. What we argue in this book is that a successful governance of religious diversity requires the development of religious literacy. Only by the development of religious literacy is it possible to avoid the two main pitfalls that religious illiteracy may produce. On the one hand, religious illiteracy is obvious in cases where issues pertaining to religion are not recognized. In Finland, this may concern the members of traditional revivalist movements or new immigrant communities who follow certain rules arising from their religious convictions, especially in relation to sexuality and family. On the other, religious illiteracy may be apparent in converse cases where religion is taken as the main explanatory factor when dealing with certain ethnic and religious groups. Islam, in particular, is a religion that tends to attract stereotypes which gloss over other personal factors, including age, class, race, gender, and cultural differences. To put it simply, not all Muslims are religious or wish to be treated as such. Both of the aforementioned pitfalls can be avoided through the ability to understand and encounter religious diversity in a constructive manner. This kind of proficiency lies at the heart of religious literacy.

\section{Approaching Religious Literacy}

In recent decades, the metaphor of "literacy" has become very popular when describing the aims of a culturally sensitive education or social services (cultural literacy) or as the ability to critically approach the media, especially social media (media literacy). In a similar fashion, we utilize the metaphor of religious literacy in order to emphasize the need for sensitivity to religion, which as a very complex matter can take many forms and play many roles in contemporary society. As such, religious literacy is a contested concept and can be understood in a variety of ways. (See Biesta et al. 2019.) Because it is also context-specific, it has been suggested that what is actually needed is religious literacies (Davie and Dinham 2019, 25-26).

Research on religious literacy has its roots in the Anglo-American world. The concept has gained momentum notably through the work of Stephen Prothero (e.g. Prothero 2007), Diane L. Moore (e.g. Moore 2015), and Adam Dinham (with his colleagues) (e.g. Dinham et al. 2009; Dinham 2015b). There are different broad views on religious literacy, among them theological, sociological, and culturalist approaches (see Dinham and Jones 2010; Kähkönen 2016). To offer some definitions for religious literacy to start with, we mention the following.

Dinham and Jones $(2010,6)$ have collected points of consensus among the different approaches:

We suggest that religious literacy lies, then, in having the knowledge and skills to recognise religious faith as a legitimate and important area for public attention, a degree of general 
knowledge about at least some religious traditions, and an awareness of and ability to find out about others.

Its purpose is to avoid stereotypes, respect and learn from others, and build good relations across difference. In this it is a civic endeavour rather than a theological or religious one, and seeks to support a strong, cohesive, multi-faith society, which is inclusive of people from all faith traditions and none in a context that is largely suspicious and anxious about religion and belief.

Diane L. Moore's definition, adopted by the American Academy of Religion, is specifically targeted at educators and aims at fostering understanding of religions. According to Moore $(2015,30-31)$,

Religious literacy entails the ability to discern and analyze the fundamental intersections of religion and social/political/cultural life through multiple lenses. Specifically, a religiously literate person will possess 1) a basic understanding of the history, central texts (where applicable), beliefs, practices and contemporary manifestations of several of the world's religious traditions as they arose out of and continue to be shaped by particular social, historical and cultural contexts; and 2) the ability to discern and explore the religious dimensions of political, social and cultural expressions across time and place.

Religious literacy has often been studied in the context of education (e.g. Conroy 2015; Moore 2014; Dinham et al. 2017; Biesta et al. 2019) but also in relation to the media (Lövheim 2012), welfare (Dinham 2015a), radicalization, and extremism (Francis et al. 2015), law (Melloni and Cadeddu 2019), political discourse (Konttori 2019), and NGOs (Siirto and Hammar 2016). In this book we approach religious literacy in different contexts, such as city politics, mosque associations, and state administration. The chapters are connected to the research project on religious literacy, funded by the Finnish Cultural Foundation (2019-2020).

In Religious Literacy in Policy and Practice, Dinham and Francis (2015, 3) summarize religious literacy, first, as a matter of general interest and, second, as something that is specific to a particular context. The book at hand combines these two approaches in order to highlight the importance of religious literacy in a pluralizing and secularizing European society while utilizing empirical cases concerning religious literacy in the national context of Finland. However, it does not treat religious literacy as taken for granted but rather as needing to be problematized as a general concept used when referring to religion and religious diversity in European society.

In a similar fashion as many other European countries, Finland has undergone rapid social change invariably linked with processes of secularization and globalization. On the one hand, Finnish society is very secular, and hence religion does not dictate what people believe or how they behave. At the same time, partly due to immigration, there is an urgent need to come to terms with growing social, cultural, and religious diversity, as well as to develop social policies that address specific issues linked with different religious traditions and arising from this diversity. (See Sorsa 2018; Illman et al. 2017; Ketola et al. 2011.) It is obvious that some sort of discrepancy exists between these two forces. Due to the process of secularization, people's knowledge and understanding of religion are diminishing at the very moment when 
it would be most needed. One answer to this problem is to develop general religious literacy (see Davie 2015).

We fully agree with Dinham and Francis that data and new theories are needed in order to complement or alter the perceptions of religion in religious education in school or in the study of religions at the university level (see also Nash and Bishop 2010; Biesta et al. 2019). Even more so, a new understanding is needed with respect to popular and media portrayals of religion, or in relation to public discussion about religion. However, we are somewhat critical of the view that, with the help of religious literacy, one could "reveal a real religious landscape", as argued by Dinham and Francis (2015, 3, italics ours). The epistemological starting point of this volume lies in social constructivism, on the basis of which we approach religious literacy as a conceptual lens that, when put into practice, can produce different versions of a religious landscape.

In Finnish society, there are many situations where there is a grave lack of mutual trust and understanding between different parties (for instance, the administration and industry). For decades, Finland was understood to be a nation that shares common values. The increase of multicultural and secular features of Finnish society has somewhat changed the situation. In order to come to terms with the complexities of a diversifying and secularizing society, it is necessary to look at religious literacy from the perspective of multi-level governance, where a state-centred analysis is broadened to the processes of decentralization of traditional administrative functions and hence to civil society, businesses or international organizations, such as the European Union. By utilizing the approach of multi-level governance, in addition to focusing on formal organizations one can also examine networks and financial instruments related to policy programs or international agreements. Moreover, multilevel governance makes it possible to take into account how cultures and religions can function as a resource and as a means of co-cooperation in the public sphere. Being a strength of society, multiculturalism enables the use of versatile governance tools. (See Martikainen 2013.)

The aim of this book is to add to the capacity for better governance, decisionmaking, and societal interaction. We are looking for ways in which religious literacy can make available operational resources for actors in multi-level governance. This knowledge is essential for religious communities, working life, public decisionmaking, and public-funded service structures. We also aim to encourage readers to find solutions based on religious literacy that go beyond traditional conflicts. The chapters of this book present new ways of working with religious communities, public authorities, and citizens by using deliberative methods to find sustainable solutions.

\section{Summary of the Chapters}

This book consists of seven chapters in total. Following the introduction, five thematic chapters investigate religious literacy in relation to both majority and 
minority religions in Finland: the Evangelical Lutheran Church, Islam, and Conservative Laestadianism. What ties these chapters together is their common aim towards understanding the forms of religious literacy, as well as religious illiteracy, present in different contexts and communities in Finnish society.

Teemu Pauha and Johanna Konttori investigate statements made by candidates in the Helsinki City Council election in 2017 regarding the plan to build "a grand mosque" in Helsinki. They ask how Islam in general and the mosque project in particular are represented in the data. In the statements, what are the blind spots regarding religion? In what ways is religion misunderstood or even misrepresented? In their analysis, Pauha and Konttori identify the main discourses, or ways of representing, Islam and the mosque project, including the strong emphasis put on the freedom of religion in general. These discourses present Islam, and the mosque project in particular, as somewhat challenging to the freedom of religion, reflecting problems that could come along with the building of the mosque, as well as vis-à-vis Islam as a religion, in relation to foreignness. The authors argue that even in a secular country, politicians need to have knowledge about religions in order to be able to make fact-based decisions regarding issues related to them and religious communities.

Tapio Nykänen and Aini Linjakumpu focus on Conservative Laestadianism, which is the biggest revival movement inside the Finnish Lutheran Church and the largest Christian revival movement in Scandinavia. In their chapter, they scrutinize the regional and municipal political role of Conservative Laestadianism in the northern parts of the Finnish "Bible Belt", where the movement has prominent support, and they also examine the business networks of Conservative Laestadians. The authors aim to understand what features of politics and business exercised by Laestadians or associated with them should be recognized or understood as "Laestadian". Moreover, they ask, what does it mean for regional public life if the religion has an effect on the actions of Laestadian politicians and entrepreneurs? Do politics and business in the core regions of the movement become "Laestadianized"? In other words, how strong is the sociopolitical and financial influence of Conservative Laestadianism in the regions where the movement has strong support?

Inkeri Rissanen, Martin Ubani and Tuula Sakaranaho focus on three particular manifestations of religious illiteracy, and they analyse how these influence the governance of religious diversity in Finnish multi-faith schools. These three manifestations of religious illiteracy, which have emerged in their previous case studies, are: (1) simplified ways of making distinctions between religion and culture, (2) an inability to recognize and handle intra-religious diversity, and (3) naturalization of the Protestant conceptions of religion, culture, and citizenship. A theme that runs across these aspects of religious illiteracy is how they reflect the tendencies of either religionization or "religion-blindness". To conclude, the chapter reflects on the question of how to develop the governance of religious diversity in Finnish schools so that the pitfalls of religious illiteracy can be avoided.

Mulki Al-Sharmani and Sanna Mustasaari draw on past research (conducted separately by each of the authors) and ongoing joint research on the processes through which Muslims in Finland secure divorces, both Islamic and civil. The authors focus on how Finnish Muslims of Somali background draw on norms of both state law 
and Islamic law in their divorce practices in a non-binary way. They also examine how certain selected Helsinki mosques understand Islamic divorce in relation to court-issued civil divorce, and how they see their role and authority vis-à-vis that of state institutions in the processes of arbitrating divorce disputes and issuing Islamic divorces. The analysis problematizes three central points. The first is the assumed homogeneity and fixedness of what is "religious" about the divorce processes and how the concept of religious literacy can advance understanding of Islamic family law with regard to women's agency. The second point is the assumed oppositional relationship between "secular" and "religious" (read Islamic) divorce reflected in state laws and discourses, as well as in Muslim divorce practices. The last point concerns the insufficient attention to the importance of gender and impact of mosque mediation and arbitration in family disputes, particularly in relation to women's agency.

Marja Tiilikainen and Tarja Mankkinen discuss in their chapter how the authorities in Finland have juggled, on one hand, the need to build good and trusted relationships with Muslim communities and to support the creation of a tolerant multicultural society, and on the other hand, the need to prevent violent radicalization and extremism in Finland without stigmatizing Muslim communities. The authors understand religious literacy as a kind of sensitivity among the authorities to religion and religious communities. Empirically, the chapter is based on analysis of two national action plans for the prevention of violent extremism, as well as Mankkinen's long-term experience with security-related issues at the Ministry of the Interior.

The book ends with a conclusion that brings together the different contexts of religious (il)literacy discussed in the previous chapters and then looks at their similarities and differences. Also considered is the impact of the book on academic research and beyond.

\section{References}

Biesta, G., Aldrige, D., Hannam, P., \& Whittle, S. (2019). Religious literacy: A way forward for religious education? A report submitted to the Culham St Gabriel's Trust. Brunel University London \& Hampshire Inspection and Advisory Services. Retrieved November 27, 2019, from https://www.reonline.org.uk/wp-content/uploads/2019/07/Religious-LiteracyBiesta-Aldridge-Hannam-Whittle-June-2019.pdf.

Conroy, J. C. (2015). Religious illiteracy in school religious education. In A. Dinham \& M. Francis (Eds.), Religious literacy in policy and practice (pp. 167-185). Bristol: Policy Press.

Davie, G. (2015). Foreword. In A. Dinham \& M. Francis (Eds.), Religious literacy in policy and practice (pp. vii-xi). Bristol: Policy Press.

Davie, G., \& Dinham, A. (2019). Religious literacy in modern Europe. In A. Melloni \& F. Cadeddu (Eds.), Religious literacy, law and history: perspectives on European pluralist societies (pp. 1728). London: Routledge.

Dinham, A. (2015a). Religious literacy and welfare. In A. Dinham \& M. Francis (Eds.), Religious literacy in policy and practice (pp. 101-111). Bristol: Policy Press. 
Dinham, A. (2015b). Grace Davie and religious literacy: Undoing a lamentable quality of conversation. In A. Day \& M. Lövheim (Eds.), Modernities, memory and mutations: Grace Davie and the study of religion (pp. 45-58). Farnham: Ashgate.

Dinham, A., \& Francis, M. (Eds.). (2015). Religious literacy in policy and practice. Bristol: Policy Press.

Dinham, A., Francis, M., \& Shaw, M. (2017). Towards a theory and practice of religious literacy: A case study of religion and belief engagement in a UK university. Religions, 8(12), 276.

Dinham, A., Furbey, R., \& Lowndes, V. (Eds.). (2009). Faith in the public realm: Controversies, policies and practices. Bristol: Policy Press.

Dinham, A., \& Jones, S. H. (2010). Religious literacy leadership in higher education: an analysis of key issues and challenges for university leaders. Report. Religious Literacy Leadership in Higher Education Programme, York. Retrieved December 16, 2019, from http://research.gold.ac.uk/id/ eprint/3916.

Francis, M., van Eck, A., \& van Twist, D. (2015). Religious literacy, radicalisation and extremism. In A. Dinham \& M. Francis (Eds.), Religious literacy in policy and practice (pp. 113-134). Bristol: Policy Press.

Illman, R., Ketola, K., Latvio, R., \& Sohlberg, J. (Eds.). (2017). Monien uskontojen ja katsomusten Suomi. Kirkon tutkimuskeskuksen verkkojulkaisuja 48. Retrieved December 16, 2019, from https://evl.fi/documents/1327140/45386794/Ktk+-+Monien+uskontojen+ja+katsom usten+Suomi/c8c8d8be-e49b-5998-3539-6b2a29a4903d.

Ketola, K., Niemelä, K., Palmu, H., \& Salomäki, H. (2011). Uskonto suomalaisten elämässä. Uskonnollinen kasvatus, moraali, onnellisuus ja suvaitsevaisuus kansainvälisessä vertailussa. Yhteiskuntatieteellisen tietoarkiston julkaisuja 9. Tampere: Yhteiskuntatieteellinen tietoarkisto, Tampereen yliopisto.

Konttori, J. (2019). Uskontolukutaito tutkimuksen kohteena. Diskursiivinen näkökulma. Uskonnontutkija-Religionsforskaren 8, 1. https://doi.org/10.24291/uskonnontutkija.v8i1.83248.

Kähkönen, E. (2016). Uskontolukutaito sekulaarin ja uskonnollisen välisenä siltana. In R. Gothóni, S. Hyväri, M. Kolkka, \& P. Vuokila-Oikkonen (Eds.), Osallisuus yhteiskunnallisena haasteena: Diakonia-ammattikorkeakoulun TKI-toiminnan vuosikirja 2 (pp. 261-274). Diak Työelämä, 7. Helsinki: Diakonia-ammattikorkeakoulu. Retrieved December 16, 2019, from http://urn.fi/URN: ISBN:978-952-493-275-2.

Lövheim, M. (2012). Religious socialization in a media age. Nordic Journal of Religion and Society, 25(2), 151-168.

Martikainen, T. (2013). Multilevel and pluricentric network governance of religion. In T. Martikainen, \& F. Gauthier (Eds.), Religion in the neoliberal age. Political economy and modes of governance (pp. 129-142). Farnham: Ashgate.

Melloni, A., \& Cadeddu, F. (Eds.). (2019). Religious literacy, law and history: Perspectives on European pluralist societies., ICLARS series on law and religion London and New York: Routledge.

Moore, D. L. (2014). Overcoming religious illiteracy: Expanding the boundaries of religious education. Religious Education, 109(4), 379-389.

Moore, D. L. (2015). Diminishing religious literacy: Methodological assumptions and analytical frameworks for promoting the public understanding of religion. In A. Dinham \& M. Francis (Eds.), Religious literacy in policy and practice (pp. 27-38). Bristol: Policy Press.

Nash, R. J., \& Bishop, P. A. (2010). Teaching adolescents religious literacy in a Post-9/11 World. Charlotte, NC: Information Age Publishing.

Prothero, S. (2007). Religious literacy: What every American needs to know-and doesn't. San Francisco: HarperSanFrancisco.

Siirto, U., \& Hammar, S. (2016). Kansalaisjärjestöt moniuskontoisen ympäristön toimijoina ja uskontolukutaidon edistäjinä. In P.-L. Rauhala, M. Jäppinen, A. Metteri, \& S. Ranta-Tyrkkö (Eds.), Kansainvälinen, ylirajainen, globaali sosiaalityö-juuria, katkoksia, uusia alkuja (pp. 178203). Sosiaalityön tutkimuksen vuosikirja. Tallinn: United Press Global. 
Sorsa, L. (2018). Uskonnolliset tavat ja julkinen tila Suomessa. Kirkon tutkimuskeskuksen verkkojulkaisuja 55. Retrieved December 16, 2019, from https://evl.fi/documents/1327140/409 00428/Ktk+-+uskonnolliset+tavat+ja+julkinen+tila+Suomessa/5067ac74-bf93-2619-d695-80a $81 \mathrm{dfd} 22 \mathrm{~b} 3$.

Open Access This chapter is licensed under the terms of the Creative Commons Attribution 4.0 International License (http://creativecommons.org/licenses/by/4.0/), which permits use, sharing, adaptation, distribution and reproduction in any medium or format, as long as you give appropriate credit to the original author(s) and the source, provide a link to the Creative Commons license and indicate if changes were made.

The images or other third party material in this chapter are included in the chapter's Creative Commons license, unless indicated otherwise in a credit line to the material. If material is not included in the chapter's Creative Commons license and your intended use is not permitted by statutory regulation or exceeds the permitted use, you will need to obtain permission directly from the copyright holder. 